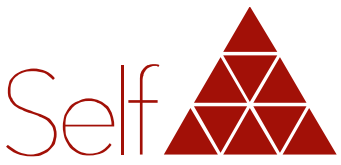

Revista do Instituto Junguiano de Săo Paulo

\title{
O corpo na produção artística da arte Medieval, no Renascimento e no Maneirismo
}

\author{
Paula Serafim DARÉ \\ Instituto Junguiano de São Paulo, São Paulo/SP, Brasil.
}

Conflito de interesses:

A autora declara não haver nenhum interesse profissional ou pessoal que possa gerar conflito de interesses em relação a este manuscrito.

\section{Resumo}

O objetivo deste trabalho é analisar o desenvolvimento da consciência coletiva na história da Europa por meio da observação de três momentos históricos da arte: a arte medieval, a renascentista e a maneirista. A análise foi feita a partir da observação das representações do corpo humano nas pinturas desses períodos. A obra de arte pode compensar a unilateralidade da consciência de uma época. A produção artística nestes três momentos apresenta características distintas, que serão abordadas sob a teoria da psicologia analítica. Para tanto, analisou-se o período histórico da Idade Média, descrevendo suas características sociais e artísticas, além das possíveis influências que a arte sofreu dos complexos culturais de cada uma das três escolas, relacionando estas influências às características da consciência e da sombra coletivas. Esta pesquisa busca compreender o desenvolvimento da consciência do homem europeu e, consequentemente, o desenvolvimento da psique ocidental.

\section{Descritores}

história da arte, Renascimento, Maneirismo (arte), história - Europa.

Recebido: 24 jul 2017; $1^{\text {a }}$ revisão: 23 jan 2018; Aprovado: 02 fev 2018; Aprovado para publicação: 06 mar 2018. 


\title{
The body in the Medieval Artistic production, in the Renaissance and in the Mannerist art
}

\begin{abstract}
The objective of this paper is to analyze the development of collective consciousness in the history of Europe through the observation of three historic moments in art: the medieval, the Renaissance and the Mannerist art. This analysis was made from the observation of the representations of the human body in the paintings of those periods. Art can compensate the onesidedness of the consciousness of an era. Art produced on these three moments present different characteristics, which will be approached through analytical psychology theory. To this purpose, the historical period of the Middle Ages was analyzed, describing its social and artistic characteristics, besides the possible influences that art suffered from the cultural complexes of each of the three schools, relating these influences to the characteristics of both collective consciousness and collective shadow. This research seeks to understand the development of consciousness in the European man and, consequently, the development of the Western psyche.
\end{abstract}

\section{Descriptors}

art - history, Renaissance, Manneirism (art), history - European. 


\section{El cuerpo en la producción artística de la Arte Medieval, en el Renacimiento y en el Manierismo}

\section{Resumen}

El objetivo de este trabajo es analizar el desarrollo de la conciencia colectiva en la historia de Europa por medio de la observación de tres momentos históricos del arte: el arte medieval, el renacentista y el manierista. El análisis se hizo a partir de la observación de las representaciones del cuerpo humano en las pinturas de esos periodos. La obra de arte puede compensar la unilateralidad de la conciencia de una época. La producción artística de los tres momentos presenta características diferentes, que serán abordadas con base en la teoría de la psicología analítica. Para ello, se analizó el período histórico de la Edad Media, describiendo sus características sociales y artísticas, además de las posibles influencias que el arte sufrió de los complejos culturales de cada una de las tres escuelas, relacionando estas influencias a las características de la conciencia y de la sombra colectivas. Esta investigación busca comprender el desarrollo de la conciencia del hombre europeo y, consecuentemente, el desarrollo de la psique occidental.

\section{Descriptores}

historia del arte, Renacimiento, Manerismo (arte), historia - Europa. 


\section{Introdução}

Ao longo da sua trajetória o ser humano produziu imagens, desde os desenhos nas paredes das cavernas (arte rupestre), passando pelos ornamentos feitos em objetos de uso cotidiano (armas, por exemplo) produzidos pelos povos nômades, e pelas imagens das Idades Média e Moderna, chegando à Contemporaneidade. Desse modo, pode-se constatar que o indivíduo tem necessidade de produzir representações: um impulso em materializar formas que confirmam uma intenção, um desejo, uma experiência vivida, uma lembrança ou, quem sabe, cristalizando por meio da imagem algo que ainda deva ser compreendido. A forma como essas imagens são representadas varia e é influenciada por circunstâncias culturais e sociais. A essas representações, bem como a uma enorme variedade de maneiras pelas quais se apresentam na música, na dança, na arquitetura e em outras formas de expressão, dá-se o nome de arte.

Embora seja difícil dar uma única definição sobre o que é arte, pois sempre seríamos demasiado reducionistas, entendemos que ela está ligada ao imaginário do ser humano, provocando em quem a produz e em quem a contempla a possibilidade de pensar. Pensar sobre si mesmo e sobre o meio que o circunda e, através da produção artística, deixar materializar símbolos que possam veicular as transformações do homem.

A proposta deste trabalho é analisar o desenvolvimento da consciência coletiva por meio da representação do corpo em três momentos artísticos europeus: a Arte Medieval, o Renascimento e o Maneirismo, perpassando os períodos históricos medieval e moderno. É importante lembrar que tomamos como referência para análise aquilo que se destaca em cada período, sem nos esquecer que a arte é processual e que há artistas em cada um dos momentos históricos tratados que destoam do que caracteriza o período.

\section{Da pré-história à era contemporânea}

Para os historiadores da arte Janson e Janson (1996), as imagens rupestres tinham um caráter mágico, com a finalidade de ritualizar os embates entre homens e animais. Como essas imagens eram realizadas pelo homem préhistórico em cavernas de difícil acesso, deduz-se que o lugar tinha localização especial, sagrada.

Em sociedades antigas mais organizadas, como a egípcia, as imagens eram representadas principalmente em túmulos e reproduziam a vida de pessoas importantes em sua passagem para a morte, mostrando seu cotidiano e seus costumes. Eram também um registro histórico, onde os faraós contavam suas conquistas. Entre os gregos e os romanos, vemos os mitos serem contados por meio das imagens produzidas em vasos, casas e templos.

Durante a Idade Média, a arte esteve a serviço da lgreja e da instrução das Escrituras, por meio de representações que contavam a história de Cristo. Iconoclasta, a arte islâmica tendeu para o caligráfico e para o geométrico. 
Na Europa medieval do século XIII, a tridimensionalidade começa a tomar forma. O Renascimento traz o reconhecimento do pintor como indivíduo, o artista adquire importância e prestígio. Na ldade Média, o artista praticamente não existia como figura de referência, todos deviam reproduzir as coisas obedecendo às regras de representação. No Renascimento, a diversidade ganha importância (Farthing, 2010).

Do ponto de vista histórico, o Maneirismo (1515/20-1600) coincide com a época da Reforma Protestante, quando há questionamentos sobre os desmandos da Igreja Católica Apostólica Romana e a proposta de uma relação direta entre o homem e sua fé. Nessa fase, a expressão artística retrata uma modificação na representação do corpo, cujos contornos tornam-se distorcidos e alongados.

Com a Contrarreforma (ou Reforma Católica), a expressão artística também se transforma, refletindo introspecção e recato, principalmente em países protestantes como a Holanda. Durante os séculos XVIII e XIX o artista aparece como crítico de uma sociedade em pleno desenvolvimento industrial, manifestando-se por meio do movimento romântico que aponta para o bucólico e se posiciona contra o materialismo. Mas, uma contradição começa a se configurar, pois estes mesmos artistas precisavam vender suas obras para sobreviver, ao mesmo tempo em que se esperava que, com sua arte, viessem a jogar luz sobre o que não era visto pela maioria (Farthing, 2010). Durante a segunda metade do século XVIII há uma grande proliferação das academias de arte, uma forma sistemática de ensinar arte. Mais tarde as academias foram atacadas e acusadas de serem demasiado conservadoras.

A arte do século XX evolui com as mudanças tecnológicas e o avanço do capitalismo. A arte moderna tem como marca a variedade de manifestações artísticas e se expande do eixo europeu. Segundo Farthing (2010): "Nova York, e não mais Paris, era a capital internacional da arte" (p. 12). Ainda segundo este autor, Andy Warhol (1928-1987) traz a popularização da arte por meio da reprodução artística de produtos industrializados, a chamada pop art (Farthing, 2010).

\section{A arte medieval, renascentista e maneirista}

As obras de arte da Idade Média não criam sensação de tridimensionalidade, elas fazem um convite para entrarmos em um mundo que não é o nosso e sim o lugar do divino, como se pode observar em "A taula de Saint Miquel" (Figuras la e 1b), de autoria do Mestre de Soriguerola (século XIII). As imagens evocam devoção e não identificação. A imagem sem perspectiva faz com que o olhar pare na superfície da tela, não permitindo que o observador entre na cena. 


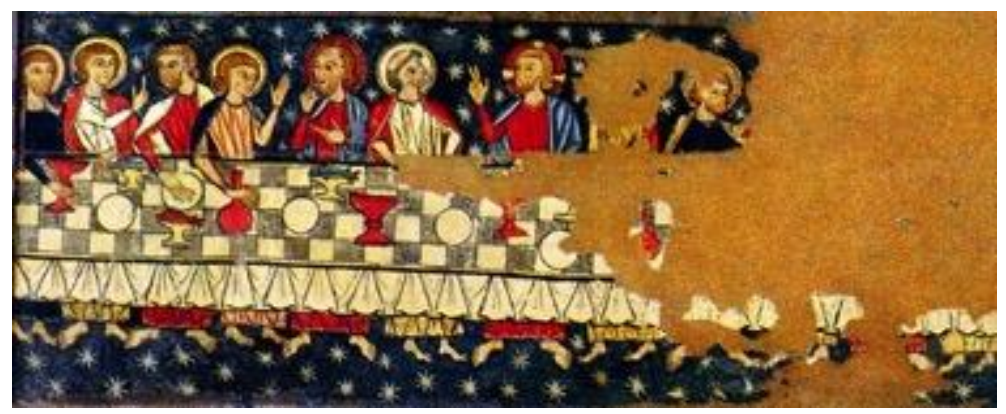

Figura 1a. Imagem em seu estado atual de uma das 13 cenas de "A taula de Saint Miquel", Mestre de Soriguerola. Reproduzida de http://www.ricardocosta.com/sites/default/files/imagens/taula/taula1.jpg

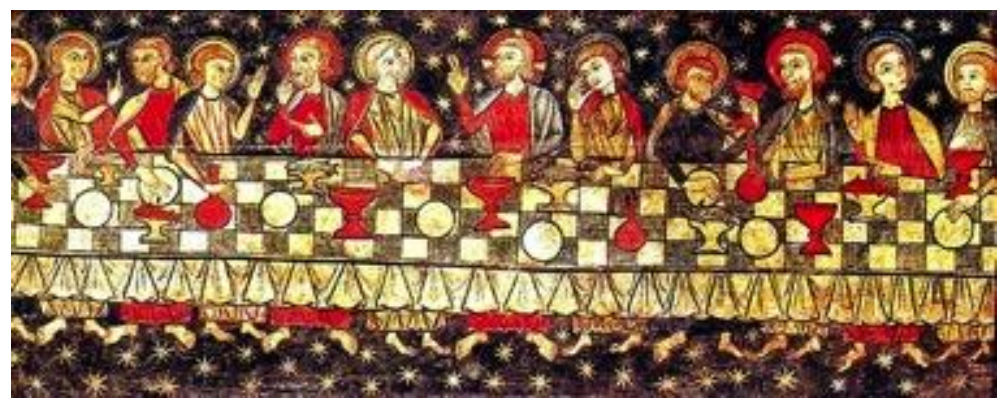

Figura 1b. Imagem reconstruída da Figura 1a. Reproduzida de

http://www.ricardocosta.com/sites/default/files/imagens/taula/taula2.jpg 
A frontalidade acentua a solenidade do encontro com a autoridade espiritual (Figura 2).

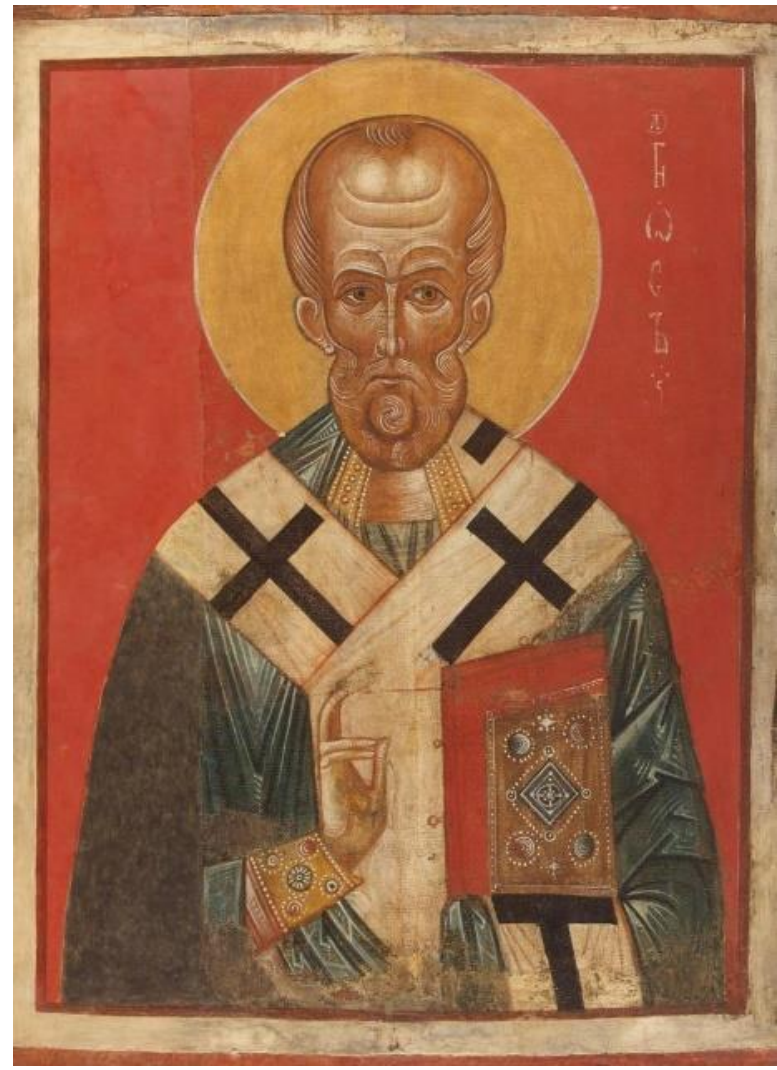

Figura 2. Ícone de São Nicolau, fim do século XIII, início do século XIV, artista desconhecido. Têmpera sobre painel $108 \mathrm{~cm}$ x 79,5 cm. Museu Hertmitage, São Petersburgo, Rússia. Reproduzida de https://i.pinimg.com/736x/04/c7/b3/04c7b38fcdcee554036271e1c6eb7f9d --christmas-history-russian-icons.jpg 
No Renascimento, Leonardo da Vinci na representação da "Última ceia" (1495) (Figura 3) apresenta um Cristo humanizado, o artista demonstra diferentes emoções entre os apóstolos e sugere a ideia de tempo, no fundo da imagem. Aqui é possível ao observador imaginar-se na cena: há luz e equilíbrio na simetria.

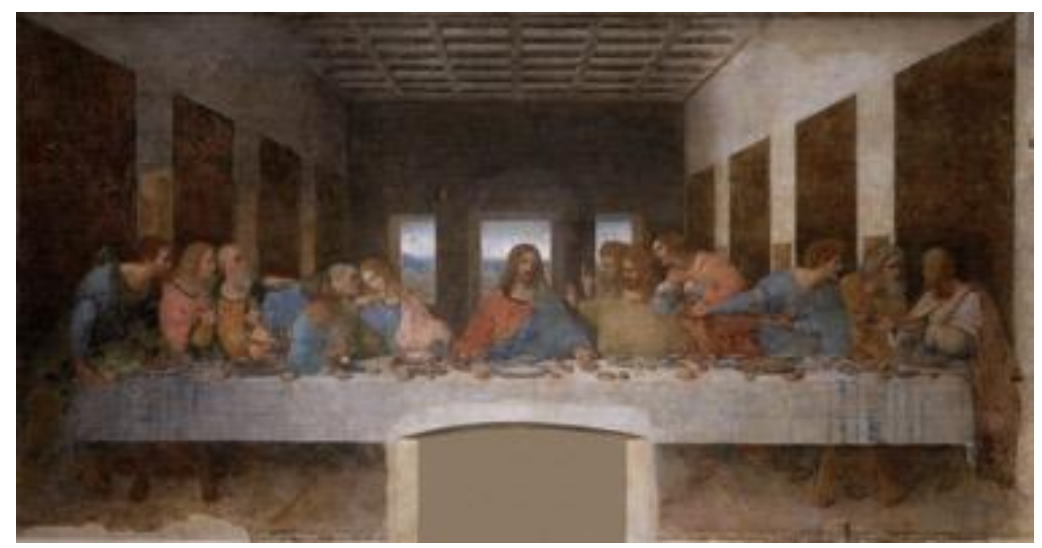

Figura 3. "A última ceia" (1495), Leonardo da Vinci. Refeitório do

Convento de Santa Maria delle Grazie, Milão. Reproduzida de https:/upload.wikimedia.org/wikipedia/commons/0/08/Leonardo_da_Vinci _\%281452-1519\%29_-_The_Last_Supper_\%281495-1498\%29.jpg

Em "A última ceia" (1592-1594) (Figura 4) de Tintoretto, obra do Maneirismo, o Cristo sai do centro da imagem, dando a impressão de um movimento para a diagonal, ao contrário do cenário mais simétrico de Leonardo da Vinci. Quem observa a obra também movimenta o olhar, havendo lugares luminosos e outros sombrios. $\bigcirc$ sagrado e o profano estão misturados. 


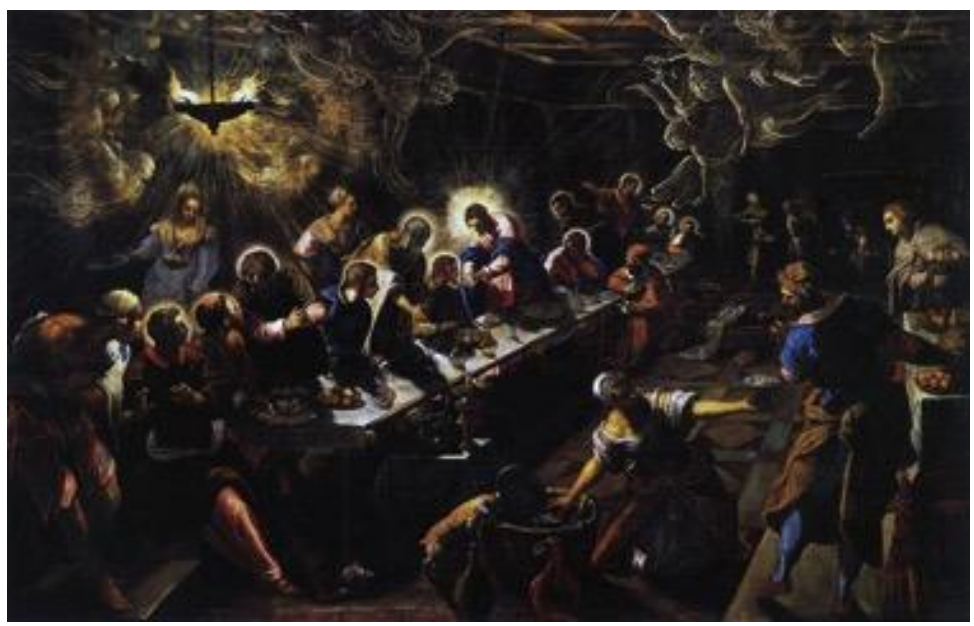

Figura 4. "A última ceia", (1592-1594), Tintoretto, San Giorgio Maggiori,

Veneza. Reproduzido de

https://upload.wikimedia.org/wikipedia/commons/4/46/Jacopo_Tintoretto_-

_The_Last_Supper_-_WGA22649.jpg

Segundo Ulson (1988), para que um quadro seja considerado arte, o mesmo deve ser reconhecido como tal por um grande número de pessoas e deve conter algo de universal. Como a obra de arte traz símbolos do inconsciente que pertencem a todos, sua contemplação permite ao indivíduo entrar em sintonia com temas universais. Assim, ao entrar em contato com uma obra de arte, o indivíduo pode ser mobilizado por uma energia que provém do inconsciente coletivo, levando-o a vivências que podem ampliar a consciência. A obra de arte pictórica eterniza imagens através das quais podemos tentar compreender o homem e seu momento histórico. Por meio destas representações, dentro de uma perspectiva analítica, realizamos uma leitura do que norteava a consciência e a sombra coletiva nestes três períodos.

A era medieval estende-se por longo período, comportando nela a arte bizantina, a arte gótica e o início do Renascimento. Já na era moderna, encontra-se a segunda parte da Renascença e o Maneirismo. De modo a facilitar a compreensão de como o corpo humano era visto e vivido, apresentamos, em linhas gerais, três momentos artísticos: a arte medieval, a renascentista e a maneirista.

A Idade Média vai do ano 476, com a queda do Império Romano do Ocidente até 1453, com a tomada de Constantinopla pelos turcos. Na chamada Alta Idade Média, que vai de século $\mathrm{V}$ ao século $\mathrm{Xl}$, houve a 
invasão pelos povos bárbaros e os romanos foram se deslocando para áreas rurais. Como os bárbaros eram um povo nômade, em sua cultura não havia preocupação em construir monumentos ou grandes moradias, sua produção artística estava ligada ao artesanato e à confecção de armas (Korovaeff, 2009).

Na Baixa Idade Média, que vai do século XII ao século XV, começa a desintegração do feudalismo. Com o advento das Cruzadas há um desenvolvimento do comércio e um despertar urbano, com o aparecimento de feiras que vendem mercadorias do Oriente. Neste período há declínio do poder católico e um incremento do trabalho no comércio e no artesanato. Começam a se organizar corporações de ofício que formaram a base do capitalismo (Korovaeff, 2009).

A Idade Média foi chamada de Idade das Trevas por alguns pensadores do Renascimento, pois a cultura greco-romana havia sido sobrepujada pelas invasões bárbaras e pelo domínio da lgreja Católica Romana, colocando na sombra os conhecimentos da Antiguidade. Outros autores como Huizinga (2013) e Le Goff (2014) refutaram esta afirmação.

\section{O corpo na arte da Idade Média}

O corpo na Idade Média ficava entre duas polaridades: ora glorificado como o corpo de Cristo, ora desprezado como fonte de desejos. Segundo Le Goff e Truong (2014):

As manifestações sociais mais ostensivas, assim como as exultações mais íntimas do corpo, são amplamente reprimidas. É na Idade Média que desaparecem, sobretudo as termas, o esporte, assim como o teatro herdado dos gregos e romanos; e os próprios anfiteatros, cujo nome passará dos jogos de estádio às disputas de espírito teológico no seio das universidades. Mulher diabolizada; sexualidade controlada; trabalho manual depreciado; homossexualidade no início condenada, depois tolerada e enfim banida; riso e gesticulação reprovados; máscaras, maquiagem e travestismos condenados; luxúria e gula associadas [...]. $\bigcirc$ corpo é considerado prisão e o veneno da alma. À primeira vista, portanto, o culto do corpo da Antiguidade cede lugar na Idade Média a uma derrocada do corpo na vida social (p. 37).

Tudo o que fosse visto como exagero na gesticulação corporal era condenado pela Igreja Católica. Os gestos, no entanto, para a sociedade de então, tinham grande significado:

Quando do ritual de homenagem vassalar e de investidura, o vassalo coloca suas mãos juntas entre as de seu suserano, que fecha as suas sobre elas: é a imixitio manuum. Depois o beijo (osculum) assinala e significa que o seu senhor o adotou em sua 
família. Assim os vassalos o são de "de boca e mão" (Le Goff \& Truong, 2014, p. 145).

Pode-se dizer que ainda hoje mantemos fortes concepções de costumes originários da Idade Média, pois a prática da contenção dos impulsos foi em seu aspecto positivo um exercício de civilidade. $\bigcirc$ homem medieval estava separado do seu corpo como veículo de realização do si-mesmo (ou Self), núcleo da interação entre consciência e inconsciente. Este homem estava crucificado entre o humano e o divino, entre o ego e o si-mesmo. Os aspectos sombrios (as características não aceitas da personalidade) do homem medieval estão ligados aos desejos, impulsos, manifestações corporais e ao feminino, entre outros.

Na Idade Média da Europa Ocidental, a Igreja Católica monopolizou a arte: as produções artísticas ficavam, em sua maioria, nos templos (Arruda \& Piletti, 1995). Segundo Gombrich (1972), quando o cristianismo se torna uma religião oficial, surge a necessidade de um espaço destinado à realização dos rituais religiosos. Antigas construções, chamadas então basílicas, foram transformadas no que viriam a ser as igrejas. Esses edifícios eram usados para audiências públicas, julgamentos e também como mercados. No século VI, o Papa Gregório I entendeu que as imagens representadas eram um modo dos ágrafos tomarem conhecimento da história. A representação pictórica dos personagens localizava-se de acordo com a importância do lugar arquitetônico. Na abside, que se transformou em altar, só são representados Cristo, a Virgem Maria e Deus Pai que são imagens repetidas também na cúpula. A arte era extremamente canônica, o artista tinha relativa autonomia em sua criação, obedecendo aos princípios religiosos. É uma arte solene que apresenta aos fiéis o reino do céu, tendo como característica a bidimensionalidade (somente são representadas altura e largura), a frontalidade das imagens ou perfil de 3/4. Há uma desmaterialização das figuras; trata-se de uma arte descarnada, portanto, menos humanizada. Poucas vezes o movimento é representado, assim, as imagens apresentam um traço de atemporalidade. $O$ corpo das figuras corresponde a sete unidades da cabeça, o rosto é a sede da expressão da espiritualidade que se dá por meio da intensificação do olhar (Nascimento, 2013).

O uso das cores também segue uma simbologia (Figura 5): o ouro, que é um valor terreno, representa o céu, traduz a riqueza do celeste; a cor púrpura, representando a paixão, é usada nos mantos de Cristo, da Virgem Maria, do imperador e da imperatriz; o azul, que também pode estar nos mantos, representa o celestial; o branco, a ressurreição; o verde, a renovação espiritual; e o preto, o caos. $O$ imperador e a imperatriz, por vezes, apresentam auréolas (Nascimento, 2013). 


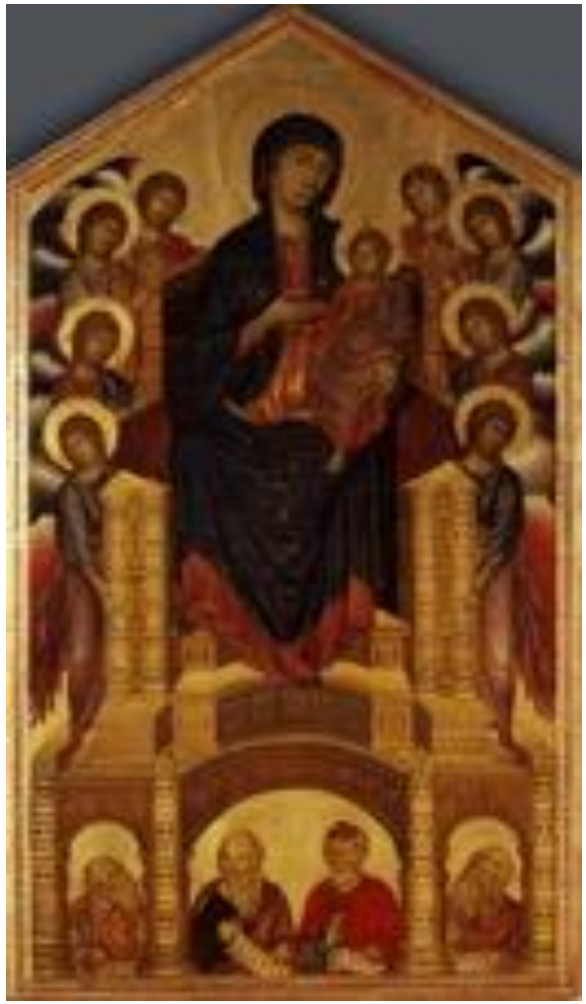

Figura 5. "Maestà", (c. 1260-1280), Cenni di Petro Cimabué, Galleria degli Uffizi. Florença, Itália. Reproduzido de https://upload.wikimedia.org/wikipedia/commons/9/9f/Cimabue_033.jpg

\section{O corpo e a arte renascentista}

A Renascença é um movimento cultural que se inicia no fim da Idade Média e avança pelo início da Idade Moderna. Nesse período, aproximadamente de 1300 a 1650, há uma redescoberta das produções artísticas e intelectuais da Grécia e da Roma antigas. Os gregos Platão, Aristóteles, Homero e o romano Cícero são revisitados e uma visão mais humanista, dando enfoque ao homem e suas realizações, se configura. Essa redescoberta do mundo clássico promoveu profundas mudanças na arte. A mitologia grega se tornou um tema artístico recorrente e as imagens vão ganhando tridimensionalidade e perspectiva. Produções artísticas de várias áreas crescem: pintura, arquitetura, escultura e literatura. Esse grande fervilhar artístico aconteceu primeiramente em Florença, na Itália, onde a família Médici dominava politicamente a República. Lorenzo de Médici, o 
Magnífico, manteve a cidade relativamente estável durante seu governo, com sua habilidade, inteligência e sensibilidade. Com a ajuda de seu mecenato, característica comum a toda família Médici, a arte floresceu (Imbroisi \& Martins, 2018; Farthing, 2010).

A Renascença é dividida em três momentos: o Trecento (Figura 6), no século XIV, que marca a transição para a arte renascentista; o Quattrocento (Figura 7), no século $X V$, que caracteriza o período áureo da Renascença; e o Cinquecento (Figura 8), no século XVI, com o fim do Renascimento e a passagem para o Maneirismo e o Barroco (Inhan, 2008). As principais características do Renascimento são: (a) o antropocentrismo, com o homem passando a ser o centro do universo, sendo capaz de explicar os fenômenos a sua volta; (b) o racionalismo, segundo o qual a razão é a base de todo o conhecimento; (c) o humanismo, com a valorização do conhecimento humano voltada ao desenvolvimento de suas potencialidades; (d) o individualismo, no qual o artista passa a assinar suas obras; e (e) a inspiração na antiguidade clássica, com a estética dos gregos e romanos como modelo ideal. A despeito da cultura pagã permear a vida dos indivíduos, em Florença, a crença cristã ainda era muito forte, com ícones, santuários e imagens da Virgem por todos os lugares (Unger, 2009). 


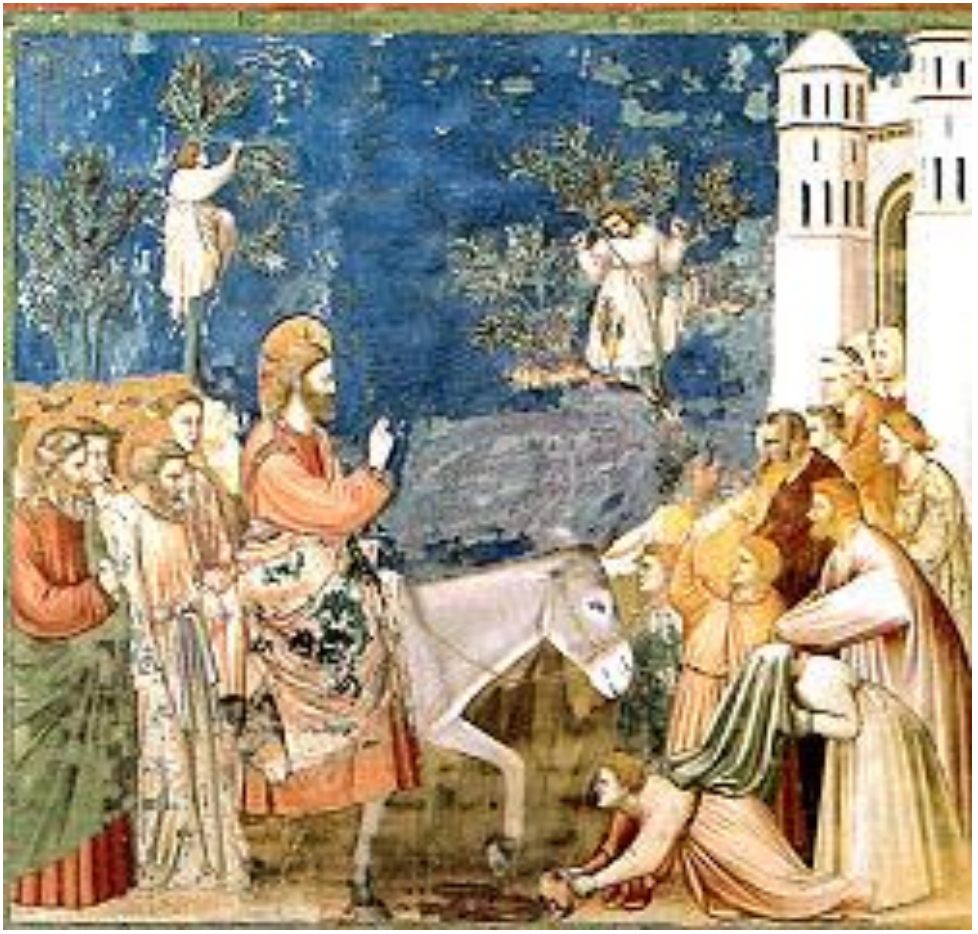

Figura 6. "Entrada de Cristo em Jerusalém", 1305/6, Giotto. Afresco.

Cappella degli Scrovegni (Capela de Arena), Pádua, Itália. Reproduzida de http://www.cbcurtis.net/benedict/Humanities\%20Site/images/lt_med_giotto _arrive.jpg 


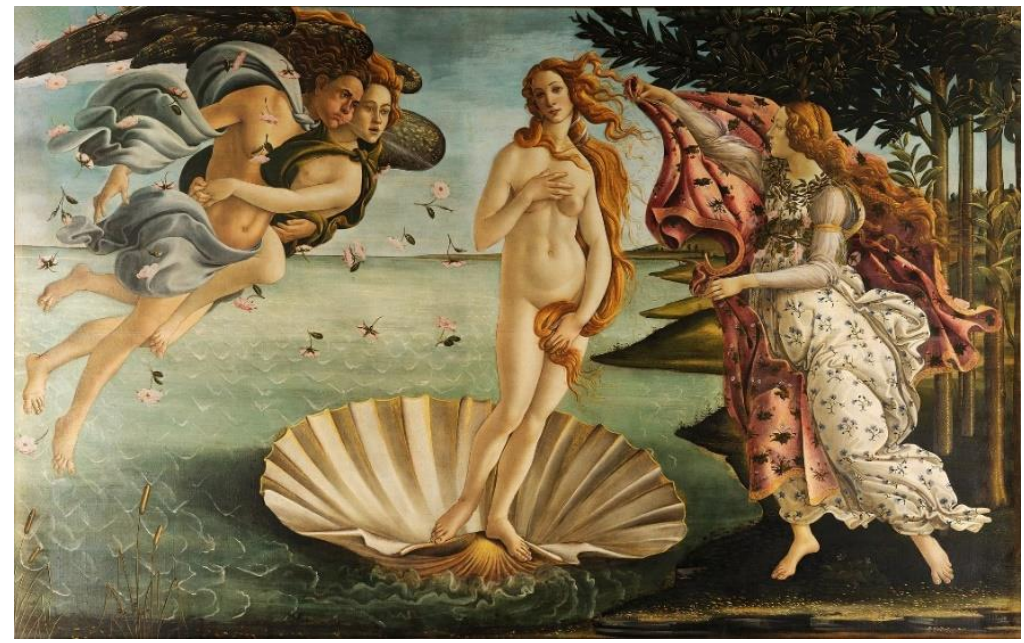

Figura 7. "O Nascimento de Vênus", 1480, Sandro Botticelli. Têmpera sobre tela, 1,74 m x 2,79 m. Galleria degli Uffizi. Florença, Itália. Reproduzida de

https://pt.wikipedia.org/wiki/O_Nascimento_de_V\%C3\%AAnus\#/media/Fil e:Sandro_Botticelli_-_La_nascita_di_Venere_-_Google_Art_Project__edited.jpg 


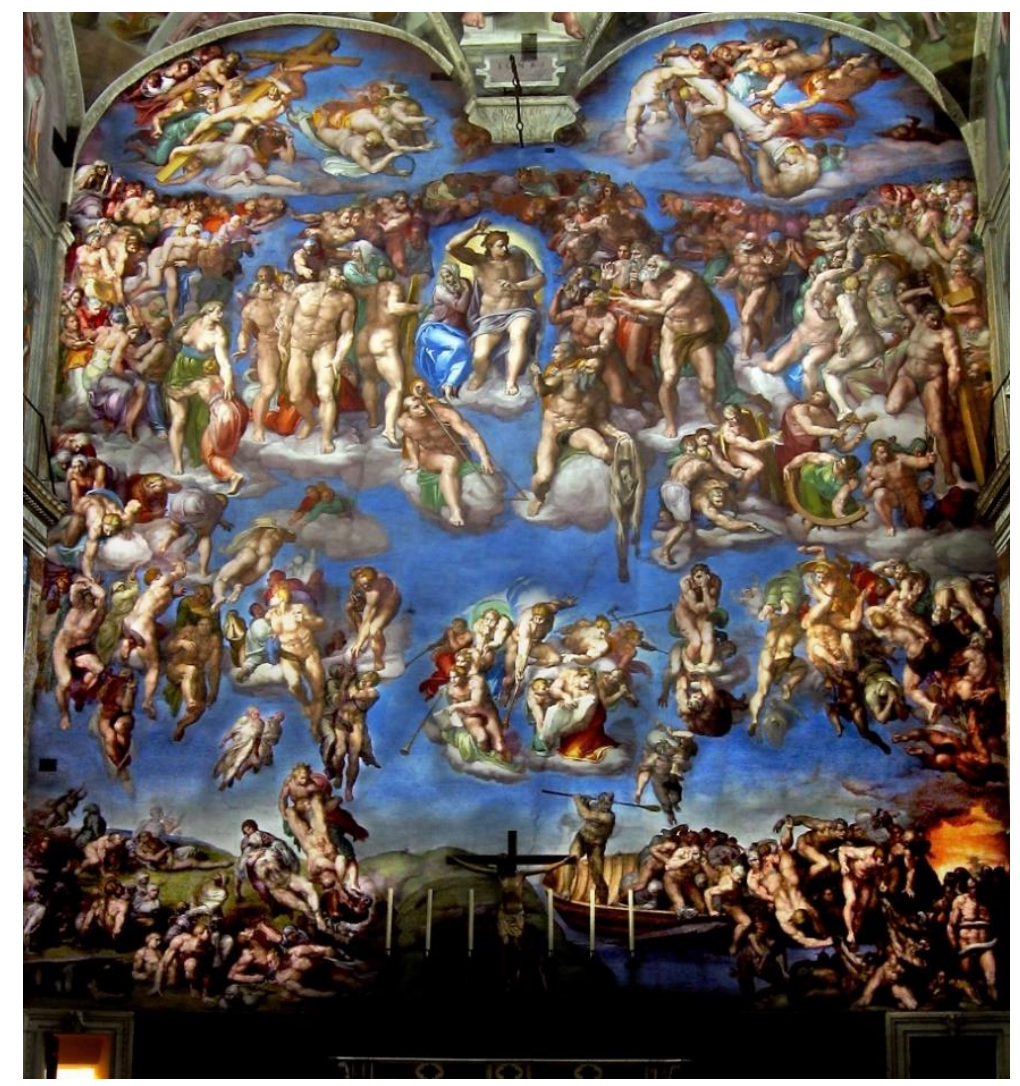

Figura 8. "O juízo final", 1534/41, Michelangelo. Afresco. Cappella Sistina

(Capela Sistina). Cidade do Vaticano, Vaticano. Reproduzida de https://commons.wikimedia.org/wiki/File\%3ATheLastJudgment.jpg

A Renascença mostra-se também como um período de grandes transformações em outras áreas. Há o aparecimento de um vocabulário grotesco em obras como "Gargântua" e "Pantagruel", de François Rabelais, e o surgimento de cientistas como Copérnico e Galileu Galilei, desvendando o funcionamento da natureza. Nessa observação da natureza havia grande interesse pelo conhecimento do corpo e seu funcionamento. Nas suas famosas dissecações, Leonardo da Vinci explorava músculos e órgãos internos. Essas mudanças culturais interferiam na vida do homem comum (Assis, 2013).

No Renascimento o homem ainda sofria forte influência religiosa, mas começava a mudar seu status dentro da consciência coletiva. Deixou de ser coadjuvante e passou a ser protagonista da própria história, e verdades passaram a ser questionadas. Os corpos aparecem nas obras de forma 
materializada, encarnada, humana. $\bigcirc$ homem e a natureza começam a ser representados juntos. $O$ corpo humano passa a ser visto e apreciado, como fonte de beleza e realização. Foi como se a vida ideal, antes reservada para após a morte, tivesse se tornado palpável, ao alcance do homem. Essa é uma importante e significativa movimentação da consciência coletiva que muda o lugar do homem no mundo.

A arte renascentista ilumina e revaloriza a estética das obras da escola clássica, trazendo profundas transformações no modelo plano e devocional visto na maior parte da Idade Média. A perspectiva, a tridimensionalidade, o homem e a natureza agora estão presentes nas obras com riqueza de detalhes, enfatiza Farthing (2010). A Renascença introduziu uma cultura laica, não religiosa. Com a retomada do mundo clássico, temas mitológicos e cenas cotidianas tomaram a temática das obras. O Renascimento estava ligado ao capitalismo, ao comércio e à ascensão burguesa que ajudaram a financiar a arte (mecenato). O humanismo, que torna o homem o centro dos interesses, passa a influenciar a temática da arte, assim como a mitologia e o cristianismo.

Havia grande rivalidade entre as principais cidades italianas Veneza, Florença e Milão, cada uma delas queria abrigar os melhores artistas. Sob os governos dos Médici, Florença tornou-se um centro de cultura e, a partir do mecenato de Cósimo, pode-se aproveitar o clima de paz e suas coleções de arte (D'Ávila, 2008). Cósimo transmitiu esses valores a seu filho Piero e ao neto, Lorenzo, o Magnífico, que desde muito cedo comandou missões diplomáticas e esteve sempre rodeado por intelectuais. Unger (2009) acrescenta que o interesse de Lorenzo pela Antiguidade definiu e modelou as produções artísticas de sua época. Para Chastel (2012), Lorenzo tornou-se uma referência em questões de bom gosto e de estética na Europa da época. Cósimo, Piero e Lorenzo de Médici reuniram em torno de si poder e cultura.

Segundo Imbroisi e Martins (2018) e Farthing (2010), as principais características da pintura, escultura e arquitetura renascentistas são: (a) o naturalismo, a representação do homem em sua beleza natural; (b) o realismo, pelo qual as imagens representam as formas como são observadas; (c) o desenvolvimento de retratos, refletindo o individualismo do homem do Renascimento; e (d) os temas mitológicos.

\section{O corpo na arte maneirista}

Maneirismo (1515-1660) é o período da história da arte que se encontra entre a Renascença e o Barroco. A palavra vem do italiano maniera, que representa uma forma particular e subjetiva do artista representar algo (Janson \& Janson, 1996). Segundo Gombrich (1972), esses artistas estudavam os desenhos das figuras humanas de Michelangelo e tentavam reproduzi-los, mas os resultados provocavam estranheza. Repetiam a maneira, mas não o espírito das obras. 
O Maneirismo se afasta da representação naturalista e do ideal clássico e desconstrói aquela harmonia proporcionada pelo equilíbrio das obras do Renascimento. A arte se afasta da natureza, rompe com os padrões de conforto para o espectador, aprofundando a experiência ali representada.

Do ponto de vista histórico estamos em plena Reforma Protestante, movimento liderado por Martinho Lutero, que condenava a venda de indulgências pela Igreja Católica Apostólica Romana, defendendo que a relação entre o homem e Deus não precisava de intermediários. A Reforma é comparada a uma revolução copernicana na religião: o indivíduo orbita em torno de sua fé e não mais em torno da instituição lgreja. Há uma nova luz sobre a religiosidade e isso se expressa na obra maneirista. $\bigcirc$ corpo e a natureza perdem seu lugar central para dar espaço a uma nova vivência espiritual, abre-se uma distância entre a natureza e a arte.

O Maneirismo vê na imitação dos modelos clássicos uma fuga do medo, nessa nova perspectiva de encontro com o divino. Para o artista maneirista, a representação clássica, demasiado harmônica, mostra-se como forma sem conteúdo. O Renascimento ainda trazia muito da religiosidade medieval. No Maneirismo o indivíduo se vê só e a arte reflete essa desconfiguração (Hauser, 1976).

O desconforto provocado pelo Maneirismo altera a ordem das coisas e a importância dada a cada uma delas. Com isso, um novo confronto do homem consigo mesmo, aprofundando ainda mais e transformando sua consciência. O homem do século XVI passou por profundas mudanças no campo social, político-econômico e religioso. A Reforma e a Contrarreforma marcaram as mudanças no campo religioso. $\bigcirc$ questionamento das práticas da Igreja Católica pela Reforma Protestante levou à realização do Concílio de Trento, acontecido entre 1545 e 1563 - uma tentativa de conter o avanço dos seguidores de Martinho Lutero. A Contrarreforma determinava a volta da Inquisição, a criação de um índice de livros proibidos e a criação da Companhia de Jesus, formada pelos jesuítas, que tinha como objetivo a catequização de povos não católicos (Arruda \& Piletti, 1995).

A arte sofreu interferências do Concílio de Trento, que restringiu corpos nus em obras destinadas às igrejas. $\mathrm{O}$ Papa Clemente VIII quis destruir o afresco de Michelangelo, "O juízo final", mas a Academia de São Lucas conseguiu impedir. Antes disso, Daniele da Volterra já havia coberto as figuras nuas do mesmo afresco, a pedido do Papa Paulo IV (Hauser, 1976).

No Maneirismo existe um desejo de elevação espiritual. Com as mudanças estilísticas na representação, vemos um desinvestimento do homem em si mesmo em busca de uma nova espiritualidade. $O$ humano contém em si o sagrado e o profano, tão bem representados nas obras de Tintoretto. As características da produção maneirista são o alongamento e a desproporção das imagens, assim como uma alteração nos cenários que se apresentam de forma complexa, como se fossem a representação de um sonho ou pesadelo. Não há uma identificação direta do espectador com a obra, como nos quadros renascentistas, devido à mudança na representação dos corpos. 
No uso das cores também predomina um tom mais frio e metálico, principalmente nas obras de El Greco (Figura 9). Além de El Greco, todas essas características estão expressas em obras de artistas como Tintoretto, Parmigianino, Pontorno, Rosso, Breughel, Bronzino, Bassano e Tasso (Janson \& Janson, 1996; Farthing, 2010).

○ espaço onde as figuras estão representadas não corresponde ao espaço natural. Surgem imagens irreais, as diagonais são bastante usadas com espaços superpovoados e, por vezes, não sabemos quem é o personagem principal. $\bigcirc$ artista maneirista abre mão do reconhecimento em favor de sua rebeldia: para os maneiristas, os renascentistas são demasiadamente bemcomportados (Hauser, 1976). A representação do corpo no Maneirismo perde a naturalidade, por vezes, de uma parte do corpo, em outras, do corpo todo, com alongamentos e entorses improváveis.

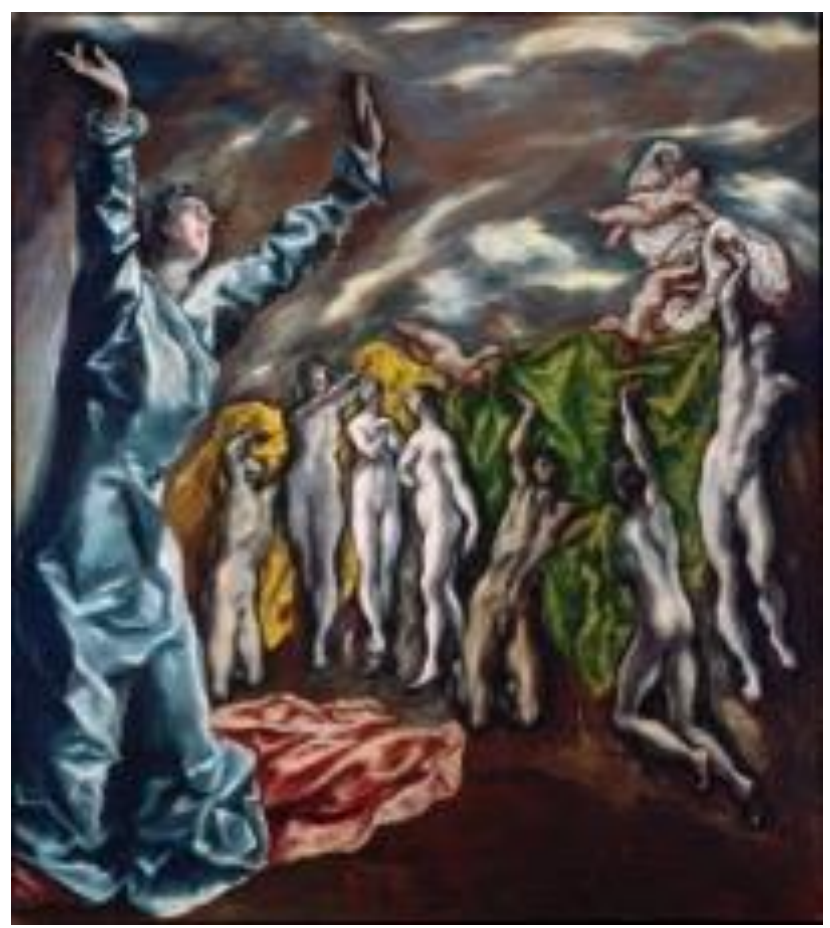

Figura 9. "A abertura do quinto selo" (ou "Visão de São João"), cerca de 1610, El Greco Metropolitan Museum of Art, Nova York, NY, EUA. Reproduzida de

https://upload.wikimedia.org/wikipedia/commons/2/2f/El_Greco\%2C_The_ Vision_of_Saint_John_\%281608-1614\%29.jpg 


\section{O corpo e sua representação na arte e na psicologia}

Do ponto de vista da psicologia clínica, não só o corpo concreto é levado em conta, como também o corpo psíquico, como ele é vivido e sua representação para o indivíduo. $O$ corpo no sonho - como ele se configura e se move na imagem do sonhador - compõe uma imagem da psique. $\bigcirc$ corpo na clínica, assim como na obra de arte, é visto como expressão da alma. A arte pode ser um caminho para pensar o indivíduo e poder compreendê-lo como aquele que transforma o processo histórico.

No corpo representado nas obras de arte medievais há algo de imaterial, existe um hiato entre a representação do corpo e o corpo do homem real, que tinha seu valor diminuído pelos conceitos de pecado e culpa, vigente na época. $O$ corpo do homem é renegado por ser fonte de pecado. A história de muitos santos está ligada ao flagelo do corpo, que remete à Paixão de Cristo. Para Le Goff e Truong (2014), o homem medieval encontrava-se preso entre várias tensões: Deus e o homem; o homem e a mulher; a cidade e o campo; a riqueza e a pobreza; a razão e a fé; a violência e a paz. Mas, a principal tensão era aquela expressa entre o corpo e a alma, retratando o corpo divinizado por um lado e maldito pelo outro.

No Renascimento acontece uma redescoberta do corpo. Segundo Lichtenstein (2004), o século XV inventou o corpo, estudando sua anatomia, formas e expressões. A princípio os corpos traziam a beleza das formas, como os modelos da Antiguidade; depois, a necessidade de retratar o natural começa a ganhar espaço. Para Sócrates, a beleza representada em um corpo só seria completa se nas características físicas estivessem impressas as características espirituais, como bondade, orgulho ou sabedoria. As proporções dos corpos descritas pelo arquiteto Marco Vitrúvio Pollio, contemporâneo do Imperador Augusto, ajudaram a definir o conceito de beleza do Renascimento. Leon Battista Alberti escreveu um importante tratado sobre pintura em 1435 onde afirma que nem tudo deveria estar explícito na pintura, era preciso deixar margem para o espectador imaginar. Alberti sugere que na tela existiria uma figura de ligação entre o espectador e o interior do quadro, que o convidava a entrar na cena.

homem do Renascimento começa a questionar a religião como única fonte do saber e coloca-se no centro de seu próprio universo. Para tanto, busca inspiração na Antiguidade Clássica a fim de produzir um novo modelo artístico. Por meio das expressões corpóreas, o artista seguia mostrando a história dos homens e seu percurso através dos tempos. A forma pela qual os indivíduos se apresentam e se reconhecem retrata o modo como eles, em cada período histórico, se definem e concebem a vida cotidiana (Le Goff \& Troung, 2014). O corpo traz em si a coagulação da alma e é uma via régia na direção de sua realização.

O corpo na obra de arte é o que nos representa, nos materializa; é a forma como nos mostramos no mundo, como ocupamos espaço, como 
interagimos, como amamos, expressamos nossas emoções e como morremos. Na revelação do corpo está a subjetividade da psique.

Acompanhando o desenvolvimento da história observa-se que novos paradigmas são estabelecidos, há sempre movimentos de avanço e recuo, experimentando o novo e transformando o passado. $O$ surgimento de novos paradigmas não raro é veiculado por meio dos artistas e de suas produções, pois é uma característica do artista ter maior proximidade com as imagens anímicas. $\bigcirc$ artista é um grande receptor que capta o que não pode ser visto pela maioria e retransmite a um grande número de pessoas, transformando a consciência coletiva.

Para James Hillman (1984), apesar de o instinto criativo estar em toda a humanidade, os artistas talvez tenham talentos inatos que facilitem a transformação psíquica do instinto, além de uma relação mais fluida com o mesmo. A criação artística não é uma escolha por meio da qual o ego diga onde quer chegar, pois isso não depende apenas de sua vontade, mas sim de sua condição, de seu estado, de modo que não atrapalhe a permeabilidade das imagens da psique à consciência. Para Guerra (2006), a arte é livre e, tal como o sonho, não pode ser aprisionada, por isso é fonte e veículo das mudanças culturais. Para Gambini (2010), a arte é subversiva, já que tira a lente pela qual estamos acostumados a ver: ela subverte a ordem da consciência.

Para Jung (1987, OC XV: 100), "a obra de arte não é a expressão de uma neurose, e a neurose seria inclusive um entrave no caminho da criatividade". A criatividade é um instinto que opera de forma independente podendo formar uma síntese entre a consciência pessoal e/ou coletiva e o inconsciente pessoal e/ou coletivo. A expressão desse processo criativo se dá por meio dos símbolos. Esses sempre expressam algo que não se pode apreender completamente e que contém em si múltiplos significados. A consciência está sempre sendo visitada por símbolos do inconsciente, que a revigoram e a nutrem, desfazendo antigas visões e lançando novos olhares sobre os fatos. Quando está ativado, o símbolo carrega energia para a consciência e chega até ela pela função transcendente, conciliadora de opostos. Esse confronto de opostos sempre leva a um novo olhar, pois de outra forma ficaríamos paralisados na perpetuação de um conflito. Esse processo pode ser definido como um caminho de autorregulação da psique.

Segundo Sharp (1991), a autorregulação da psique segue as seguintes etapas: o indivíduo sente uma dificuldade de adaptação, seja no plano exterior, seja no interior, e a energia disponível para o ego fica diminuída; com a regressão da libido, conteúdos inconscientes são ativados, gerando tensão e, por vezes, sintomas; então, a função transcendente, por meio dessa tensão gerada, começa a formar símbolos, na tentativa de levar conteúdos do inconsciente à consciência. À medida que esses símbolos vão sendo assimilados, há uma progressão da libido.

inconsciente funciona de modo compensatório em relação à consciência e a emergência dos símbolos reflete essa compensação. Os símbolos que 
aparecem na obra de arte podem atuar no coletivo como os símbolos oníricos operam na consciência individual, fazendo a ponte com aquilo que nos é desconhecido. Segundo Glauco Ulson (1988):

[...] nome tomado emprestado da matemática, a função transcendente designa a relação entre os números inteiros e os imaginários. Esta função é simbolizadora e não encerra nada de místico, como seu nome sugere. É assim chamada por expressar a capacidade que o símbolo tem de transcender opostos (p. 49-50).

Para Barcellos (2006), tal como fazia o alquimista no trabalho com os metais, a arte é uma projeção do espírito na matéria, é uma forma de encarnação de uma ideia e, para tal, usa o mundo interior e o exterior. Ao dar forma para algo sobre o qual ainda não se tem uma ideia clara do que seja, são dadas as condições para que a realidade interior e a exterior se encontrem e, por meio desse trabalho criativo, encontrar um significado. $\bigcirc$ trabalho criativo opera junto à função transcendente, organizando em uma obra aquilo que ainda não tem uma forma definida.

O trabalho alquímico é uma metáfora para o processo analítico, onde a prima materia, representada pelos conteúdos inconscientes, passa por transformações, decompondo-se, separando-se e ganhando vida. A obra de arte pode ser entendida de forma análoga ao trabalho alquímico, no qual vão se materializando aspectos do inconsciente pessoal e coletivo. Quando a obra de arte traz esse confronto com o desconhecido, Jung a nomeia de visionária. Já aquelas produções artísticas que expressam vivências pessoais do artista são por ele nomeadas de psicológicas. A obra de arte que traz aspectos do inconsciente coletivo pode corrigir ou compensar uma atitude da consciência coletiva de um determinado período histórico (Jung, 1987).

Aspectos do artista revelam-se em sua obra, mas a obra não se resume a ele (artista), a sua história e a seus problemas. Na obra de arte, o que é pessoal e o que é coletivo estão unidos. A obra realizada por um artista sempre terá sua história e seu repertório, com os quais ele trabalha a matéria-prima; porém, quando o autor vai além disso (o que não depende de determinação pessoal), a matéria trabalhada fala não somente para ele, mas para o coletivo (Guerra, 2006).

artista como pessoa pode ser doente ou saudável, mas como criador deve ser entendido pela sua produção, que o transcende do ponto de vista pessoal. $\bigcirc$ artista capta a energia dos símbolos ativados e a transforma, de acordo com seu talento, trazendo luz à consciência da coletividade. Esse impulso criativo muitas vezes ignora as condições psíquicas do artista, impondo-se a ele (Jung, 1987). Segundo Jung (1987): "Elas [as obras de arte] nada evocam do que lembra a vida cotidiana, mas tornam vivos os sonhos, as angústias noturnas, os pressentimentos inquietantes que despertam nos recantos obscuros da alma" (OC XV: 143).

Para Jung (1988), é possível enxergar a criatividade como a manifestação de um complexo autônomo, que se impõe à consciência, ele não está à 
disposição do ego, mas se manifesta de acordo com suas demandas. É o que se convencionou chamar inspiração (Barcellos, 2006). Na psicologia analítica, o complexo é um conjunto de ideias ou imagens carregadas de energia psíquica. Estas ideias tendem a se ligar por meio de um elo associativo a determinados arquétipos, que muitas vezes se manifestam de forma independente, perturbando o fluxo da consciência (Sharp, 1991). Os complexos são a fonte propulsora da construção onírica, bem como dos sintomas. Do ponto de vista coletivo, os complexos atuam na cultura de um povo pelas experiências traumáticas repetitivas às quais a sociedade foi exposta. Sua dinâmica de funcionamento reproduz a autonomia do complexo individual (Wahba, 2008). Para Nunes (2012), os complexos culturais seriam, portanto, um conjunto de atitudes e de valores que atuam de modo inconsciente em uma cultura ou grupo.

Muitos artistas relatam o quanto são tomados por uma força durante o processo criativo, embora nem sempre esta força esteja em sintonia com o artista, podendo ter um caráter avassalador. $\bigcirc$ artista pode passar de condutor a conduzido no processo criativo; o foco deixa de ser o indivíduo e passa a ser a obra. Quando a criação se dá dessa forma pode-se falar da atuação de um complexo autônomo. Quando um artista veicula um símbolo, esse pode estar além da compreensão do espectador e da sua própria compreensão, que está inserida na consciência coletiva de sua época (Jung, 1987).

A base do complexo é o corpo, que tem como alicerces as esferas somática e psíquica. Quando um complexo é ativado, a psique e o corpo reagem a essa manifestação (Ramos, 1990). A identidade do indivíduo está profundamente vinculada ao complexo do ego, que pode ser definido como o conjunto de percepções a respeito de si e que carrega grande quantidade de energia. A percepção dessa identidade cresce à medida em que o ser consegue se perceber como uma entidade separada do outro. $\bigcirc$ corpo dá contorno concreto a esses limites.

A consciência nasce do inconsciente e desenvolve-se por meio de padrões. $O$ ego, que é o centro da consciência, se desenvolve, diferenciando-se do inconsciente e adaptando-se ao meio. A consciência surge a partir das percepções sensoriais do mundo e da representação psicológica que essas experiências ativam. A consciência organiza as experiências dentro dos paradigmas de tempo, espaço e causalidade. $O$ ego tem origem somática e psíquica. Somática, pois só através do corpo pode vivenciar a consciência e o corpo é o primeiro contorno que será definido como eu; e psíquica na sua capacidade de gerar uma percepção de identidade e de continuidade. A memória é o que nos dá uma noção de identidade: "Só podemos existir conscientes de nós mesmos se formos capazes de lembrar o que fizemos ontem e planejar o que iremos fazer amanhã", afirma Grinberg (1997, p. 69). 
A imagem do corpo humano é formada pela percepção do corpo pessoal, somada à percepção do corpo coletivo, que a humanidade traz em si arquetipicamente. Os arquétipos são conteúdos típicos para todos os seres humanos, formas que se repetem em culturas diferentes. As manifestações arquetípicas mostram que há uma tendência ao reproduzir experiências, não em seu conteúdo, mas em sua forma. A temática vivenciada pode ser arquetípica, mas a experiência de vivê-la é individual. $\bigcirc$ tempo e o lugar onde $o$ arquétipo se manifesta são tingidos por características culturais de onde o indivíduo está inserido. Quando um arquétipo está contido em uma obra ela adquire grande força, pois não é somente a voz do artista, mas a voz da humanidade que está presente ali. Uma imagem primordial foi traduzida por meio do talento do artista. Aí se encontra a função social da arte, que corrige a atitude unilateral da consciência coletiva de uma época.

A observação das obras de arte dos três momentos históricos - arte medieval, renascentista e maneirista - provoca sensações diferentes. As obras medievais levam a uma atitude de reverência. As obras da Renascença trazem equilíbrio ao olhar. Já as do período maneirista provocam uma espécie de reviravolta, de inquietude.

C corpo visto através das obras de arte contém algo de particular em relação a outros documentos históricos, pois as pinturas não correspondem somente a uma representação factual. Em outras palavras, elas têm caráter prospectivo, indicam para onde está se dirigindo a energia psíquica. É uma tendência antecipada pelo inconsciente. Esta função prospectiva, segundo Jung (1991), se compõe de percepções, memórias, pensamentos e sentimentos subliminares, de modo que muitas vezes o inconsciente tem mais elementos para visualizar uma situação prognóstica que a consciência.

A consciência coletiva se organiza por meio de padrões de comportamento que definirão um grupo: o que estiver fora desse padrão comporá a sombra coletiva. A sombra é um arquétipo que diz respeito a tudo o que foi reprimido ou que, por alguma razão, não pôde desenvolver-se, tornando-se impulsos não civilizados. As características sombrias são frequentemente experimentadas por meio da projeção, ou seja, ao ver no outro aquilo que não é reconhecido em si mesmo (Sharp, 1991).

Para Nunes (2012), a reunião de um grupo em torno de um arquétipo promove a formação de uma identidade cultural, mas o mesmo fator que promove essa identidade coletiva também é o formador da sombra, onde ficam relegados os elementos que confrontam as características do ideal de ego do grupo. Manter conteúdos sombrios longe da consciência coletiva requer mecanismos repressivos, cujo objetivo é criar modos mais padronizados de pensar e agir.

Assim como o indivíduo diferencia-se do coletivo ao longo de seu percurso para encontrar uma posição que o defina frente a suas demandas internas, e o adapta ao meio dentro de um equilíbrio dinâmico -, a consciência coletiva também pode seguir esse fluxo, de modo que um grupo, povo ou etnia se 
transforme e adquira singularidades. Pode-se chamar este processo de individuação da cultura. Se a consciência coletiva de um povo ou de um grupo está demasiadamente polarizada, símbolos compensatórios emergem visando à manutenção do fluxo entre a consciência e o inconsciente coletivo.

homem medieval atravessou a transformação da religião politeísta para a monoteísta. Os imperadores já não encontravam na antiga religião romana uma forma de instituir uma dinastia mais forte e o monoteísmo foi uma via para alcançar tal ambição, identificando Deus com o imperador, que tentava não apenas se salvar, mas também ao Império (Le Goff, 2007).

A religião cristã tem características patriarcais: o arquétipo regente é o do pai. $\bigcirc$ arquétipo paterno é um organizador de limites, leis, obrigações e hierarquia. A forma de operar essa organização é separar tudo em polaridades: bem e mal, justiça e injustiça, certo e errado. Essa polarização dificulta a atuação da função transcendente e o ego permanece preso nos opostos (O'Kane, 1994). Na Idade Média, a imagem de Deus permanece separada em sua dimensão salvadora e punitiva, manifestando-se de forma ambígua dentro da consciência coletiva. Diante dessa cisão a figura de Deus é imposta pelo poder, pois quando aspectos patriarcais preponderam em uma cultura, ela tende ao dogmatismo e a comportamentos autoritários (Nunes, 2012).

Segundo Fernandes (2004), a mensagem de Jesus traz a dinâmica da alteridade, da relação entre opostos. Cristo traz a síntese dos arquétipos matriarcal e patriarcal sem negá-los. No entanto, o modo patriarcal de se relacionar com a religião se manteve e ratificou a visão de que o divino está fora do homem, configurando uma religiosidade repleta de dogmas e repressões.

Para Carlos Byington (1991): "A história simbólica do Cristianismo é, assim, demarcada pelo conflito entre a imposição do padrão de alteridade no Self Cultural e sua repatriarcalização reacionária oriunda das tradições culturais Judaicas e Romanas e da obra uniformizadora e repressiva da Inquisição" (p. 8).

Na Idade Média, a cristalização dos preceitos da consciência coletiva provocou um acúmulo de energia inconsciente, que atuou de modo sombrio, principalmente por meio dos abusos da Inquisição. A busca de bodes expiatórios, a perseguição às mulheres e a caça às bruxas atendiam à necessidade de manutenção da consciência coletiva e à voracidade pelo poder (Byington, 1991). Com a economia limitada pela capacidade de consumo e pela falta do conceito de lucro, a sociedade se tornou imóvel, rígida e conservadora. Faltava ao homem medieval "o dinamismo intelectual criado pela ideia de competição" (Hauser, 1972, p. 255).

A interpretação de que o pecado original era sexual - e não relacionado à apropriação do conhecimento divino - foi fruto de manipulações ideológicas, com objetivo não de instruir os fiéis, mas de manipulá-los (Le Goff \& Truong, 2014). O corpo e a mulher, ligados a essa interpretação do 
pecado original, não tinham outro destino senão a sombra. Havia uma cultura de ascetismo: a negação dos desejos físicos como caminho para a espiritualidade e a purificação. Byington (1991) afirma que a Igreja teoricamente protegia Cristo e seus ensinamentos, mas, na verdade, "os despotencializava como símbolos transformadores" (p. 8); a figura do demônio tornou-se muito poderosa, representando desobediência à ordem vigente, que era centralizadora: ela atuaria de modo sombrio.

Nas obras de arte da Idade Média há representações do Cristo sofredor (Figura 10) e imagens do Cristo Pantocrator (Figura 11), geralmente apresentadas com meio corpo (busto), com a mão direita dando uma benção e a esquerda, na maioria das vezes, segurando um livro, o fundo dourado indicaque Cristo está no céu. $\bigcirc$ Cristo Pantocrator reúne características humanas e divinas do Cristo, que depois de viver seu sofrimento na Terra, retorna ao seu lugar divino. Esses dois Cristos, o sofredor-irmão e o todo-poderoso, refletem a ambiguidade do Cristo da Idade Média, o que colocava o homem medieval frente a um Deus que ora punia, ora salvava. No entanto, o Cristo encarnado, que transcendeu a morte vivida do modo mais miserável que havia para época, acena para o povo com a possibilidade de que todos podem ser salvos (Le Goff, 2007). 


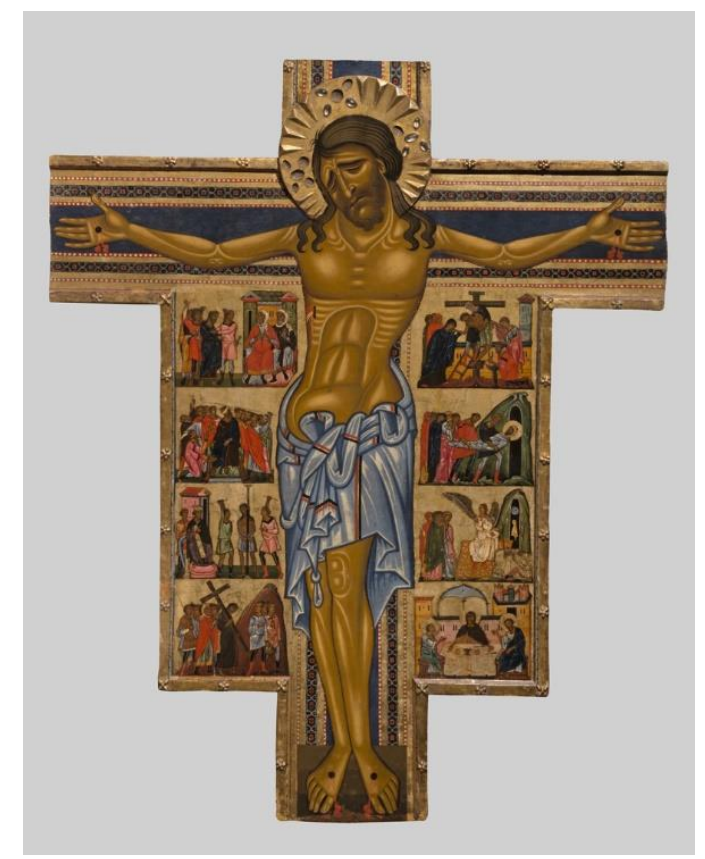

Figura 10. "Mestre da Cruz". Crucificação e oito histórias da paixão de Cristo, final do século XII/Início do século XIII. Têmpera sobre painel, 250 cm x 200 cm. Galleria degli Uffizi. Florença, Itália. Reproduzido de https://i.pinimg.com/originals/55/31/6b/55316beba218b0028bf 275df1c0933be.jpg 


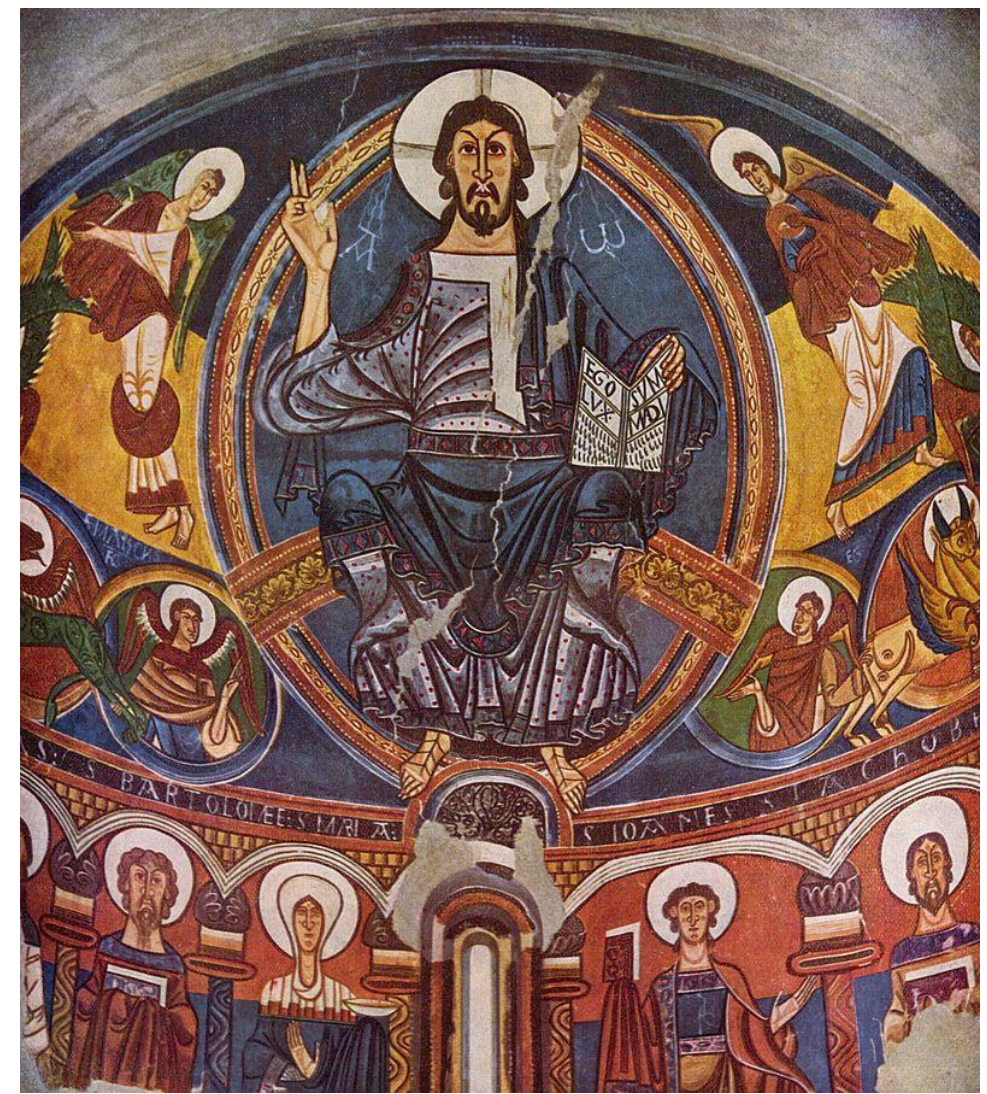

Figura 11. "Cristo Pantocrátor". Afresco. Museo Nacional de Arte Catalán. Barcelona, Espanha. Reproduzida de https://www.ancient.eu/uploads/images/2157.jpg?v=1485680556

Os deuses gregos tinham uma comunicação mais próxima com os homens, que se concretizava por meio de oferendas e cultos à natureza. As esculturas em forma humana, apesar de uma estética idealizada, e as histórias dos deuses com seus sentimentos deveras humanos, promoviam uma identificação e tornavam esses deuses mais acessíveis. No monoteísmo, apresenta-se um Deus que é uma referência, mas, como está destituído de seus aspectos sombrios, torna-se inacessível e isso se reflete na arte com corpos etéreos, desmaterializados.

homem medieval trazia fortes traços do pensamento animista das sociedades primitivas. Tudo para ele era dotado de grande simbolismo e todo o seu julgamento estava em um lugar que era externo a ele. As pinturas não tinham um espaço conhecido, eram alheias ao homem. Se na arte medieval não havia espaço conhecido, no Renascimento o homem e a 
natureza passaram a ser incluídos. No Renascimento o homem passou a admirar o belo no mundo, sacralizando o humano e humanizando o sagrado.

O Renascimento reinaugurou o nu na pintura. Ao aproximar o espectador do tempo e do espaço retratados, estimulou a imaginação. $\bigcirc$ homem renascentista voltou seu olhar para o corpo e para o meio que o circundava: o desenvolvimento da ciência diminuiu a luz do misticismo que imperava na Idade Média. O Renascimento trouxe de volta a função estética da arte que durante a maior parte da Idade Média esteve a serviço da educação religiosa e a religião não tolerava a arte como entidade independente (Hauser, 1972). A arte e a religião caminharam juntas por um longo período, talvez porque a arte seja uma forma do homem materializar o incognoscível, o mistério.

Para Jung (2011), a religião é a possibilidade de uma modificação na consciência por meio da experiência com o numinoso, conteúdo psíquico com grande impacto emocional na consciência. A religião, com seus rituais e sacramentos, promove uma atitude de reverência e humildade frente ao divino. Segundo Jung (2011), toda religião arraigada em um povo e em uma época traduz o seu funcionamento psíquico. $\bigcirc$ que tem grande valor para o povo ou para o indivíduo adquire um status divino, caso haja uma diminuição na atribuição desse valor, outro mistério será nomeado.

No Renascimento, outros valores passaram a povoar a consciência coletiva: o homem adquiriu potência na aquisição de conhecimento, que antes era monopólio da Igreja, e isso o libertou da submissão, the deu consistência. Surgiu a erotização do corpo e a proliferação dos retratos, o que ratifica a confirmação da existência e da identidade do indivíduo. No naturalismo da Renascença, a realidade conhecida passou a ser representada por meio da natureza, e o homem expressou seu lugar no mundo tornando-se o centro da temática artística. Ao contrário da obra medieval, na obra renascentista o indivíduo pode se identificar na imagem representada.

No Renascimento ficaram relegados à sombra o desarmônico, o disforme e o mal humano (a dor, a doença, a imperfeição), pois representavam o oposto da identidade cultural renascentista. Jung (1995) afirma que "No nível espiritual recém-adquirido se estabelece agora uma relação com o mundo e com a natureza que, ao contrário da atitude antiga, não mais sucumbe a magia do objeto, mas pode observá-lo refletindo a seu respeito" (OC V: 113).

A filosofia humanista está na base do pensamento renascentista, onde o homem é investido de potência e de poder de transformação por meio do conhecimento. $O$ homem torna-se o centro do universo.

Na passagem para a obra maneirista o corpo na obra de arte se transforma novamente. $O$ equilíbrio perde espaço e a desproporção dos corpos, com cenários complexos, toma forma. No Renascimento a arte ficou engessada na perfeição. Artistas como Bosch (Figura 12), fogem a essa regra, podemos 
sugerir que Bosch trazia em sua obra aspectos sombrios do período. $O$ artista maneirista rompeu com este equilíbrio que o aprisionava. No Maneirismo o homem se permitiu mergulhar na fonte criativa onde os paradoxos coexistem. Para Jung (2009):

Surpreendentemente, o paradoxo pertence ao bem espiritual mais elevado. $O$ significado unívoco é um sinal de fraqueza. Por isso a religião empobrece interiormente quando perde ou reduz seus paradoxos; no entanto, a multiplicação destes últimos a enriquece. Pois só o paradoxal é capaz de abranger aproximadamente a plenitude da vida. A univocidade e a não contradição são unilaterais e, portanto, não se prestam para exprimir o inalcançável (OC XII: 18).

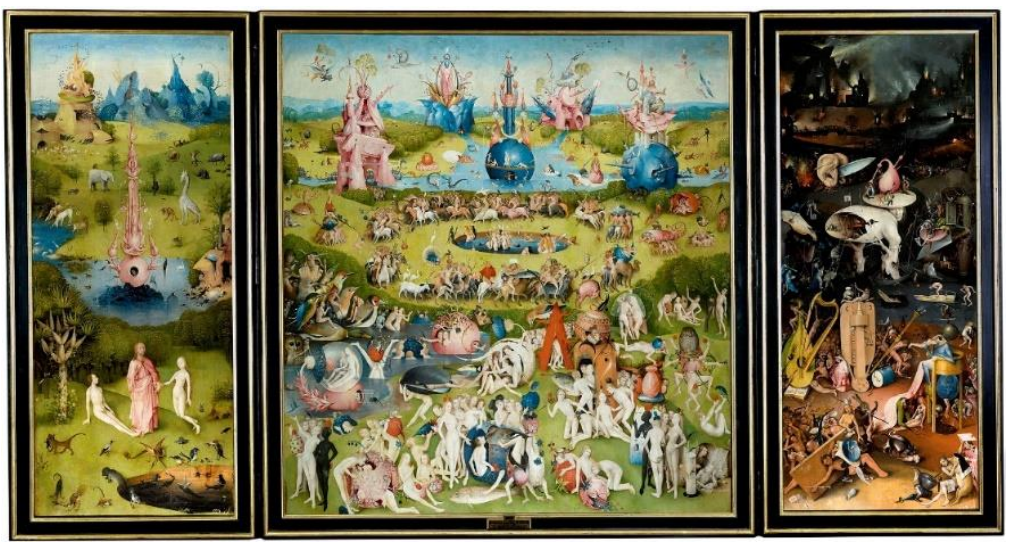

Figura 12. "O jardim das delícias 1500, Hieronymus Bosch. Óleo sobre painel. Painel central: 2,19 m x 1,94 m. Painéis laterais: 2,19 m x 0,96 cada. Museu do Prado. Madri, Espanha. Reproduzido de https://en.wikipedia.org/wiki/The_Garden_of_Earthly_Delights\#/media/File: El_jard\%C3\%ADn_de_las_Delicias,_de_El_Bosco.jpg. By Hieronymus Bosch - Galería online, Museo del Prado. Public Domain, https://commons.wikimedia.org/w/index.php?curid=45147809

No Maneirismo o homem se defronta com o sagrado e essa experiência pode ser vivida de modo esmagador. Foi um momento em que o homem tentou criar um contínuo entre ele e Deus. O corpo maneirista parece adquirir características góticas, alongando-se como o templo; há uma reaproximação com o místico e um desinvestimento do corpo. A figura humana foi novamente espiritualizada. Não há no Maneirismo uma negação do mundo, mas parece existir uma busca de diálogo com o espiritual, preenchendo-o de subjetividade (Hauser, 1972). Penso que, na obra maneirista, as ligações com o real foram desfeitas em favor de uma interpretação subjetiva da realidade, nela foi explorado o espaço fictício que 
saía do espaço conhecido e mergulhava no inverossímil; tornaram-se aspectos sombrios as certezas, a perfeição, o naturalismo e o equilíbrio. $\bigcirc$ mundo revestido de luz e de equilíbrio perdeu a profundidade e o sentido. Vive-se uma nova forma de religiosidade; valores medievais foram reinvestidos de atenção e o homem saiu do centro. A atenção pareceu voltar-se para o caminho entre o homem e a religiosidade, que se dá por meio da experiência individual do artista, a sua maneira.

\section{Considerações finais}

A arte, assim como os ritos, é uma forma de entrar em contato com o mistério, fazendo uma ponte com o Self, mantendo a conexão dentro-fora, interior-exterior, e alimentando o fluxo que permite a transformação da consciência. Na formação da consciência de um grupo há sempre um arquétipo norteador que confere identidade aos membros e ao coletivo. Tudo o que descaracterizar essa identidade estará consequentemente na sombra. A representação do corpo na obra de arte demonstra as alterações da consciência coletiva, uma vez que o corpo reflete as percepções que o homem tem de si mesmo e do momento histórico que o circunda.

As obras de arte podem retratar a manifestação das mudanças psíquicas e sociais de uma época, abrindo caminho ao que ainda está por vir. Ao seguirmos suas manifestações estaremos, em paralelo, observando os movimentos da consciência de um período, seus aspectos luminosos e sombrios. Como no sonho, a obra de arte pode ratificar uma atitude da consciência ou corrigir sua unilateralidade. Podemos observar esse movimento de correção da unilateralidade da consciência no Renascimento em relação à Arte Medieval, retirando o corpo da sombra, e no Maneirismo em relação ao Renascimento, relativizando a razão e a perfeição.

As alterações da consciência coletiva podem ser percebidas nas representações do corpo. A arte traz novas leituras e perspectivas. É uma forma de conhecer épocas e lugares, um registro histórico do tempo.

Sociedades se transformam, coletiva e individualmente. Se enxergarmos uma sociedade como um corpo, veremos neste corpo saúde e doença, harmonia e desproporção. Toda a produção artística produzida por este corpo coletivo - nas artes plásticas, na literatura, na arquitetura ou em outras formas de expressão artística - pode trazer aspectos desse homem coletivo, quais são suas aspirações, dores, conquistas, sua sombra e seus complexos culturais. Podemos metaforizar dizendo que a arte é o processo de análise desse corpo coletivo onde, por meio das imagens, como no sonho, a sociedade cultiva a alma. Acredito que se imaginarmos que o corpo da Idade Média sonha, diríamos que esse corpo está na sombra e que o poder e a salvação estão projetados no divino. $O$ corpo renascentista que sonha uniu no símbolo do corpo a alma e a matéria, antes dissociadas, e nesse momento parece que tudo tomou seu lugar, como quando temos uma revelação, um insight. Sentimos esse conforto até hoje ao apreciarmos uma obra renascentista. 
Mas, esse corpo social e cultural novamente sonhou, pois ele caminhou em sua individualização coletiva, e o homem maneirista tem um sonho que perturba e inquieta, mistura o sagrado e o profano, desmaterializa e distorce, levando esse corpo social a experimentar sua solidão e sua humanidade. Quando o corpo maneirista de novo sonhar acordará nos braços do Barroco.

A arte se mantém trazendo a realidade e as contradições da sociedade. A velocidade de nossos tempos faz com que fiquemos soterrados de imagens, mas ao sermos capturados por uma entre tantas, podemos abrir uma janela para além de onde estamos.

\section{Referências}

Arruda, J. J., \& Piletti N. (1995). Toda a história: história geral e história do Brasil. São Paulo: Editora Ática.

Barcellos, G. (2006). Voos e raízes: ensaios sobre a imaginação, arte e psicologia arquetípica. São Paulo: Agora.

Byington, C. (1991). Prefácio. In H. Kramer, \& J. Sprenger, O martelo das feiticeiras. Rio de Janeiro: Rosa dos Tempos.

Chastel, A. (2012). Arte e humanismo em Florença na época de Lourenço, o Magnífico: estudos sobre o renascimento e o humanismo platônico. São Paulo: Cosac Naify.

D’Ávila, L. F. (2008). Cósimo de Médici, memórias de um líder renascentista. São Paulo: Ediouro.

Farthing, S. (Ed.). (2010). Tudo sobre arte: os movimentos e as obras mais importantes de todos os tempos. Rio de Janeiro: Sextante.

Fernandes, R. R. (2004). A psicologia profunda no Novo Testamento. São Paulo: Vetor.

Gambini, R. (2010). Com a cabeça nas nuvens. Pro-Posições, 21 (2): 149_ 159.

Gombrich, E. H. (1972). A história da arte. São Paulo: Círculo do Livro.

Grinberg, L. P. (1997). Jung, o homem criativo. São Paulo: FTD.

Guerra, M. H. M. (2006). Arte e transcendência. Jung \& Corpo, 6(6): 45-53.

Hauser, A. (1972). História social da literatura e da arte (Vol. 1). São Paulo: Artegráfica.

Hauser, A. (1976). Maneirismo: a crise da Renascença e o surgimento da arte moderna. São Paulo: Editora Perspectiva.

Hillman, J. (1984). O mito da análise. Rio de Janeiro: Paz e Terra.

Huizinga, J. (2013). O outono da Idade Média: estudo sobre as formas de vida e de pensamento dos séculos XIV e XV na França e nos países baixos. São Paulo: Cosacnaify. 
Imbroisi, M., \& Martins, S. (2018). Renascimento. Recuperado em 1 de março de 2018, de http://www.historiadasartes.com/nomundo/arterenascentista/renascimento/

Inhan, L. Renascimento (Coleção qwero saber). (2008). São Paulo: Escala. Janson, H. W., \& Janson, A. F. (1996). Iniciação à história da arte. São Paulo: Martins Fontes.

Jung, C. G. (1987). O espírito na arte e na ciência. In Obras Completas (Vol. $\mathrm{XV})$. Petrópolis, RJ: Ed Vozes.

Jung, C. G. (1988). Nietzsche's Zarathustra: Notes of seminars given in 19341939. (J. Jarret, Ed.; Bollingen Series XCIX). Princeton, NJ: Princeton University Press.

Jung, C. G. (1991). A natureza da psique. In Obras Completas (Vol. VIII/2). Petrópolis, RJ: Editora Vozes.

Jung, C. G. (1995). Símbolos da transformação. In Obras Completas (Vol. V). Petrópolis, RJ: Editora Vozes.

Jung, C. G. (2009). Psicologia e alquimia. In Obras Completas (Vol. XII). Petrópolis, RJ: Editora Vozes.

Jung, C. G. (201 1). Psicologia e religião. In Obras Completas (Vol. XI/1). Petrópolis, RJ: Editora Vozes.

Le Goff, J. (2007). O Deus da Idade Média: conversas com Jean-Luc Pouthier. Rio de Janeiro: Civilização Brasileira.

Le Goff, J. \& Truong, N. (2014). Uma história do corpo na ldade Média. Rio de Janeiro: Civilização Brasileira.

Lichtenstein, J. (Org.). (2004). A pintura: textos essenciais: a figura humana (Vol. 6). São Paulo: Editora 34.

Korovaeff, C. K. (2009). Mistérios e revelações da Idade Média (Coleção quero saber). São Paulo: Escala.

Nunes, C. A. (2012). Los caprichos, de Francisco Goya: manifestações da sombra coletiva espanhola (Dissertação de mestrado). Programa de estudos pós graduados em Psicologia Clínica. Pontifícia Universidade Católica PUC, São Paulo, Brasil.

O'Kane, F. (1994). A sombra de Deus: reflexões sobre a depressão e a dimensão religiosa da existência. São Paulo: Axis Mundi.

Ramos, D. G. (1990). A psique do coração. São Paulo: Cultrix.

Sharp, D. (1991). Léxico junguiano. São Paulo: Cultrix.

Ulson, G. (1988). O método junguiano. São Paulo: Ática.

Unger, M. J. (2009). O magnífico. São Paulo: Larousse.

Wahba, L. (2008). Arte e cultura. Junguiana, 26: 73-78. 
Minicurrículo: Paula Serafim Daré - Psicóloga clínica. Especialista em Cinesiologia pelo Instituto Sedes Sapientiae, analista do Instituto Junguiano de São Paulo (IJUSP), membro da Associação Junguiana do Brasil (AJB), filiada à International Association for Analitical Psychology (IAAP).

E-mail: pauladare@hotmail.com 